Regiony, metropolie, miasta

ISSN 1899-3192

e-ISSN 2392-0041

\author{
Adam Drobniak \\ Uniwersytet Ekonomiczny w Katowicach \\ e-mail: adam.drobniak@ue.katowice.pl
}

\title{
HYBRYDYZACJA ROZWOJU - PRĘ̇̇NOŚĆ I DYNAMIKA ROZWOJU POLSKICH MIAST DEVELOPMENT HYBRIDIZATION - RESILIENCE AND DEVELOPMENT DYNAMICS OF POLISH CITIES
}

\author{
DOI: $10.15611 / \mathrm{pn} .2017 .467 .02$ \\ JEL Classification: R58
}

Streszczenie: Artykuł dotyczy problematyki związanej z poszukiwaniem wyjaśnienia istotnych zróżnicowań dynamiki rozwoju polskich miast niezależnych od wielkości ośrodka miejskiego. Rozważania prowadzone są w kontekście nowej koncepcji rozwoju związanej z hybrydyzacją. Celem opracowania jest, z jednej strony, prezentacja zmian dynamiki rozwoju miast, $\mathrm{z}$ drugiej zaś wykazanie braku powiązań między pogłębiającym się zróżnicowaniem dynamiki rozwoju miast a wielkością polskich ośrodków miejskich. W warstwie metodycznej artykuł bazuje na analizie dokumentów, analizie indeksów dynamiki zestawionych w portfele dla wymiarów porównujących dynamikę sytuacji: gospodarczej, finansowej, społecznej i demograficznej 223 polskich miast. Miasta zostały pogrupowane zgodnie z metodyką EUROSTAT, tj. od 20 tys. do 100 tys. mieszkańców, od 100 tys. do 250 tys. mieszkańców, od 250 tys. do 500 tys. mieszkańców, od 500 tys. do 1 mln mieszkańców oraz powyżej $1 \mathrm{mln}$ mieszkańców.

Słowa kluczowe: miasta, dynamika rozwoju, hybrydyzacja.

Summary: The article refers to issues linked with the search for explanation of significant development diversity of Polish cities unrelated to their size. Considerations are carried out in the context of new concept of development i.e. hybridization. The aim of the paper is on the one hand a presentation of the dynamics of urban development, and on the other, a demonstration of the absence of links between deepening diversification of the dynamics of urban development and the size of Polish cities. Methodologically the paper is based on a desk-research method, and on the analysis of the dynamics of indices compiled in portfolios for comparing the dimensions of the cities dynamics in the following conditions: economic, financial, social and demographic. The analysis includes 223 Polish cities over 20,000 inhabitants organized in groups according the EUROSTAT methodology.

Keywords: cities, development dynamics, hybridization. 


\section{Wstęp}

Artykuł stanowi wprowadzenie do badań empirycznych nad zagadnieniami zmian w zakresie dynamiki rozwoju w miastach polskich interpretowanych w kategoriach hybrydyzacji rozwoju. Zaprezentowana analiza jest konsekwencją wyników projektu badawczego Narodowego Centrum Nauki (nr 2011/01/B/HS5/03257) pn.: „Koncepcja 'urban resilience' a miasta poprzemysłowe w Europie", realizowanego w latach 2011-2014, przy wsparciu międzynarodowej sieci badawczej Regional Studies Association pn.: „Transition and Resilience for Post-Industrial Agglomerations in Central Europe" (2011-2013). Celem artykułu jest, z jednej strony, prezentacja zmian dynamiki rozwoju miast, z drugiej zaś wykazanie braku powiązań między pogłębiającym się zróżnicowaniem dynamiki rozwoju miast a wielkością polskich ośrodków miejskich.

Uzasadnienia dla tak sformułowanego celu można poszukiwać w następującym problemie badawczym: w jaki sposób weryfikować i oceniać zróżnicowanie dynamiki rozwoju miast polskich w oparciu o koncepcję hybrydyzacji. Miasta polskie w latach 2004-2014 rozwijały się w kontekście znacznej zmienności zewnętrznych uwarunkowań rozwoju. Istotne z poznawczego punktu widzenia jest wykazanie, w jakim stopniu wielkość miast determinowała ich dynamikę rozwoju w wymiarach związanych z gospodarką, sytuacją finansową, sytuacją społeczną i demograficzną. Uzyskane rezultaty badań stanowią przyczynek do szerszych analiz na temat poszukiwania szczegółowych przyczyn zmienności i hybrydyzacji rozwoju miast, a także formułowania zaleceń dla ekonomiki miejskiej w zakresie doboru instrumentów programowania procesów rozwoju miast.

\section{Hybrydyzacja rozwoju}

Pojęcia „hybrydy” i „hybrydyzacji” stały się ostatnio bardzo popularne w różnych wymiarach praktycznej aktywności społeczno-ekonomicznej i środowiskowej człowieka. Niemniej na obecnym poziomie wiedzy kategorie te nie doczekały się gruntownych opracowań teoretycznych. Pojęcia „hybrydy” i „hybrydyzacji” można odnaleźć m.in. w opracowaniach dotyczących:

- globalizacji, gdzie hybrydyzacja pojmowana jest jako „ciągłe mieszanie kultur” [http://www.dictionary.com/browse/hybrid],

- nanostruktur, gdzie hybrydyzacja utożsamiana jest z procesem mieszania orbit atomów na rzecz stworzenia nowych orbit [http://www.chemicool.com/definition/hybridization.html],

- aplikacji mobilnych, gdzie hybrydyzacja oznacza łączenie technologii i oprogramowania WEB z oprogramowaniem pierwotnym danego urządzenia mobilnego [http://developer.telerik.com/featured], 
- przemysłu samochodowego, gdzie pojazdy hybrydowe zasilane są przez silnik spalinowy na paliwo konwencjonalne oraz silnik elektryczny wykorzystujący energię zgromadzoną w baterii akumulatorowej [http://www.afdc.energy.gov/ vehicles/electric_basics_hev.html],

- ochrony środowiska, gdzie podejście hybrydowe oznacza adresowanie i podejmowanie działań prośrodowiskowych we współpracy z lokalną społecznością i instytucjami krajowymi przez działania łagodzące oparte na agendach politycznych [Rio Declaration, 1992],

- medycyny, gdzie system hybrydowy dotyczy m.in. rozwiązań w zakresie usztywnienia układu kostnego wraz z wielokanałową funkcjonalną elektroniczną stymulacją umożliwiającą poruszanie się [http://www.rehab.research.va.gov/jour/ 09/46/3/Kobetic.html],

- dostarczania energii, gdzie system hybrydowy łączy nowe technologie odnawialnych źródeł energii z tradycyjnymi technologiami wytarzania i przechowywania energii [http://www.opde.net/en/technologies/hybrid-systems],

- budownictwa, gdzie dom hybrydowy oferuje przestrzeń modyfikowalną. Tego rodzaju adaptacyjność umożliwia wykorzystanie domu w celach mieszkalnych, związanych z pracą zawodową lub też do celów lokalnej społeczności [http:// www.iba-hamburg.de].

Hybryda i hybrydyzacja wiążą się zatem z takimi pojęciami, jak: łączenie kultur, kombinacja technologii, działanie we współpracy, wielokanałowość funkcjonalna, połączenie rozwiązań konwencjonalnych $\mathrm{z}$ alternatywnymi, uzyskiwanie funkcji modyfikowalnych na rzecz poprawy adaptacyjności.

W wymiarze ogólnym hybryda, hybrydyzacja to pojęcia, których synonimami są: odmienność, labirynt, krzyżowanie, scalanie, łączenie, mieszanie. To wytwór, produkt stworzony przez interakcję dwóch odmiennych kultur, tradycji. To „coś” pochodzące z różnorodnych źródeł lub skomponowane z elementów różnego rodzaju i pochodzenia [http://www.dictionary.com/browse/hybrid]. Łączenie kultur, technologii, funkcji prowadzi do rozwiązań hybrydowych, tj. posiadających odmienne własności od składników, które stanowiły ich podstawę.

W wymiarze polityki miejskiej i regionalnej pojęcia hybrydy i hybrydyzacji można odnaleźć u Golubchikova, który badając i wyjaśniając zróżnicowania rozwoju miast rosyjskich, formułuje założenia wyjaśniające wysoki poziom zróżnicowania dynamik rozwoju ośrodków miejskich w oparciu o wzajemne interakcje między dziedzictwem postsocjalistycznym a siłami neoliberalnego kapitalizmu. Jego zdaniem hybrydyzacja rozwoju w wymiarze miejskim i regionalnym to: „wzajemne zakorzenienie dziedzictwa socjalizmu i neoliberalnego kapitalizmu, które wspólnie wytwarzają hybrydowe przestrzenie transformacji - czyli „osobliwe” przestrzenie geograficzne dostrajające się do wymogów kapitału, ale łączące się z dotychczasowym dziedzictwem postsocjalistycznym, poprzemysłowym" [Golubchikov, Badyina, Makhrova 2014]. Zdaniem Golubchikova rozwój hybrydowy w ujęciu przestrzennym jest rodzajem rozwoju nierównomiernego (uneven development), wynikające- 
go z oddziaływania sił neoliberalnego kapitalizmu, dla których w zakresie efektywnej alokacji kapitału liczą się te miejsca w przestrzeni, które oferują zadowalający zwrot z inwestycji. Równocześnie hybrydyzacja rozwoju jest skutkiem dziedzictwa postsocjalistycznego, w tym poprzemysłowego, które doprowadziło do określonej, specyficznej akumulacji kapitału. W sensie społeczno-ekonomicznym oznacza to lokalizację w danej przestrzeni określonego rodzaju infrastruktury społecznej i technicznej, określonego rodzaju działalności gospodarczych, określonego rodzaju kapitału ludzkiego i społecznego. Dziedzictwo postsocjalistyczne w wymiarze miejskim i regionalnym ujmowane jest zgodnie z koncepcją „ścieżki-zależności” i „zamknięcia" (path-dependance, lock-in). Tak sformułowana hybrydyzacja rozwoju jest w konsekwencji połączeniem specyfiki miejsca, mniej lub bardziej sprzyjającej siłom neoliberalnego kapitalizmu, czego efektem jest różnorodność dynamik rozwoju nie zawsze korespondująca ze skalą i rangą jednostek przestrzennych.

Tematyka znacznego różnicowania dynamiki rozwoju miast postsocjalistycznych została także podjęta przez Sýkorę oraz Bouzarovsky’ego [2012]. Transformacja społeczno-ekonomiczna dokonująca się w krajach postsocjalistycznych uwidacznia się przede wszystkim w wymiarze miejskim, gdyż miasta stanowią podstawowe ośrodki wzrostu i przemian [Sýkora 2009]. Niemniej, gdy część z miast postsocjalistycznych szybko adaptuje się do nowych warunków (grupa: post-transition według [Leetmaa, Tammaru, Anniste 2009]), część nadal zachowuje dawne struktury. Ujęcie Sýkory i Bouzarovsky’ego skupia się na interpretacji procesów transformacji miast post-socjalistycznych przez ,wielotorową dynamikę transformacji”' (multiple transformation dynamics), będącą efektem przenikania się czynników społecznych, instytucjonalnych i przestrzennych - przy czym, zdaniem badaczy, czynniki instytucjonalne odgrywają w procesach transformacji rolę dominującą. Zatem hybrydyzacja oznacza rzeczywistość społeczną, gospodarczą i przestrzenną, będącą konsekwencją rekombinacji elementów dziedzictwa socjalistycznego i sił kapitalizmu [Smith, Swain 1998; Pavlinek 2003].

\section{Uzasadnienie badań nad hybrydyzacją rozwoju miast}

Zarysowana przez Golubchikova koncepcja hybrydyzacji rozwoju stanowi interesujące podejście badawcze do wyjaśnienia zróżnicowań w zakresie dynamiki rozwoju miast i regionów Polski. Jak dowodzą badania prowadzone nad prężnością miejską i regionalną w Polsce [Drobniak 2014; Drobniak 2016b], a także w regionach Europy Środkowej [Suchaček 2012a, 2012b; Wink 2014], dynamika rozwoju w ujęciu lokalnym i regionalnym w ostatnich dwóch dekadach cechuje się:

- znacznym zróżnicowaniem poziomu dynamiki w wymiarach: aktywności podmiotów gospodarczych, wzrostu PKB, inwestycji, liczebności patentów, wielkości dochodów budżetowych, wielkości bezrobocia i pomocy społecznej, aktywności kulturalnej, aktywności społecznej, zmian demograficznych; 
- brakiem jednoznacznych powiązań między dynamiką rozwoju a wielkością ośrodka miejskiego. Przykładowo część z miast polskich liczących od 20 tys. do 100 tys. mieszkańców oraz te w przedziale od 100 tys. do 250 tys. mieszkańców wykazują podobną lub wyższą dynamikę rozwoju od miast większych, tj. o liczbie mieszkańców od 250 tys. do 500 tys. i powyżej;

- ograniczonymi możliwościami formułowania ogólnych zależności w zakresie dynamiki rozwoju, m.in. w postaci trendów, pomiędzy badanymi zmiennymi określającymi wymiary dynamiki rozwoju miast i regionów.

Powyższe wnioski powodują, iż ograniczonego znaczenia $\mathrm{w}$ ich interpretacji nabierają dotychczasowe prawa związane m.in. z wielkością i rangą ośrodków miejskich. Stosując prawo Zipfa [Duranton, 2007; Żółkowska 2016] w ujęciu ekonomicznym, w kontekście przestrzennej dystrybucji miast różnej wielkości i rangi, można zauważyć, iż ośrodki miejskie cechujące się większą populacją, większą gęstością zaludnienia oraz wyższą rangą w podziale administracyjnym powinny równocześnie wykazywać większą dynamikę rozwoju odnoszoną przykładowo do poziomu przedsiębiorczości, umiędzynarodowienia czy szybszego spadku poziomu bezrobocia [McCann, Ortega-Argilés 2015, s. 1294]. Uogólniając, należałoby zatem oczekiwać, iż dynamika rozwoju dużych ośrodków miejskich powinna przewyższać tę rejestrowaną w ośrodkach mniejszej skali. Wstępne badania empiryczne [Drobniak 2016a] wskazują, iż zależności między skalą ośrodków miejskich w Polsce a ich dynamiką rozwoju cechuje daleko idąca złożoność relacji.

Koncepcja hybrydyzacji rozwoju, w tym jej elementy związane $\mathrm{z}$ rozwojem nierównomiernym, wynikającym $\mathrm{z}$ sił neoliberalnego kapitalizmu (uneven development: [Massey 1984; Harvey 2005]) oraz dziedzictwem postsocjalistycznym, w tym poprzemysłowym odczytywanym w kontekście „ścieżki-zależności” (path-dependance: [David 2005]) oraz „zamknięcia” (lock-in: [David 2005]), stanowią użyteczny koncept teoretyczny do bardziej pogłębionych badań nad dynamiką rozwoju miast. Dalsze uszczegółowienie koncepcji hybrydyzacji rozwoju stanowi punkt wyjścia do poszukiwania i wyjaśnienia przyczyn: znaczących zróżnicowań dynamiki rozwoju, braku powiązań między dynamiką rozwoju a wielkością i rangą ośrodka miejskiego. Badania nad koncepcją hybrydyzacji mogą ponadto zostać wykorzystane do weryfikacji ograniczonych możliwości formułowania ogólnych zależności w zakresie dynamiki rozwoju miast i regionów, co z kolei znajduje bezpośrednie przełożenie na rozwiązania przyjmowane w polityce miejskiej i regionalnej.

\section{Wstępne badania nad hybrydyzacją rozwoju polskich miast}

\section{Założenia metodyczne}

Celem przeprowadzonych badań empirycznym było wskazanie różnic w dynamice rozwoju miast różnej wielkości mierzonej potencjałem ludnościowym w Polsce w przekroju wybranych wskaźników. Okres zgromadzonych danych obejmował lata 2004-2014, ze względu na znaczną zmienność uwarunkowań rozwoju, tj. zarówno 
pozytywnych (np. dostęp do zewnętrznych źródeł finansowania rozwoju w dwóch pełnych okresach programowania unijnego), jak i negatywnych (np. globalny kryzys finansowy i spowolnienie gospodarcze). W ujęciu podmiotowym badania uwzględniały grupę 223 miast polskich w podziale na miasta: od 20 tys. do 100 tys. mieszkańców, od 100 tys. do 250 tys. mieszkańców, od 250 tys. do 500 tys. mieszkańców, od 500 tys. do $1 \mathrm{mln}$ mieszkańców, powyżej $1 \mathrm{mln}$ mieszkańców. Zaproponowany podział miast uwzględniał typologię stosowaną przez EUROSTAT. Biorąc pod uwagę wstępny charakter badań, w ujęciu przedmiotowym diagnozowane wymiary rozwoju miast ograniczono do wymiarów związanych z dynamiką: gospodarki (zmiany liczby osób fizycznych prowadzących działalność gospodarczą oraz liczby spółek handlowych z udziałem kapitału zagranicznego), sytuacji finansowej gmin (zmiany wpływów z tytułu podatku PIT oraz CIT), sytuacji społecznej (zmiany liczby bezrobotnych oraz liczby gospodarstw domowych korzystających z pomocy społecznej według kryterium dochodowego), sytuacji demograficznej (zmiany liczby ludności i wskaźnika starzenia się). Dynamika zmian wskazanych wymiarów rozwoju miast podlegała pomiarowi z wykorzystaniem indeksów dynamiki o stałej podstawie. W większości wskaźników za rok bazowy przyjęto 2004, natomiast ze względu na dostępność danych statystycznych w kilku wymiarach za rok bazowy przyjęto 2008 lub 2009 rok. Na potrzeby wnioskowania na temat zróżnicowań w dynamice rozwoju wykorzystano metodę portfelową umożliwiającą analizę otrzymanych wyników w układach dwuwymiarowych. Pomocniczo, dla zobrazowania trendów zmian, posłużono się metodą regresji liniowej.

W analizowanej grupie miast mieszka 48,0\% ludności Polski. Na ich terenie działa 52,5\% ogółu osób fizycznych prowadzących działalność gospodarczą w kraju oraz 78,5\% ogółu spółek handlowych z udziałem kapitału zagranicznego. Dochody z tytułu PIT są o 16\% wyższe niż przeciętnie we wszystkich gminach w Polsce, dochody zaś z tytułu podatku CIT o 18,5\% wyższe niż przeciętnie w kraju. Gospodarstwa domowe korzystające z pomocy społecznej w analizowanych miastach stanowią 40,9\% ogółu gospodarstw korzystających z tego rodzaju pomocy w Polsce.

\section{Wyniki badań}

W wymiarze gospodarczym dotyczącym przedsiębiorczości (osoby fizyczne prowadzące działalność gospodarczą) oraz umiędzynarodowienia gospodarki (spółki handlowe z udziałem kapitału zagranicznego) - por. rys. 1 - dynamika zmian w każdej z badanych grup miast jest różnorodna. Zarówno miasta mniejsze (od 20 tys. do 100 tys. mieszkańców), jak i miasta większe (przykładowo od 500 tys. do 1 mln mieszkańców) wykazują wysoką, jak i niską dynamikę wzrostu - głównie w zakresie przedsiębiorczości. Dynamika wzrostu odnosząca się do umiędzynarodowienia gospodarki dla większości z analizowanych miast jest wysoka oraz nie jest powiązana ze skalą demograficzną miast. Rysunek 1 wskazuje, iż miasta o mniejszym potencjale ludnościowym mogą wykazywać podobną, a nawet wyższą dynamikę wzrostu w tym wymiarze. 
W wymiarze sytuacji finansowej wszystkie $\mathrm{z}$ badanych miast wykazują pozytywną dynamikę wzrostu z tytułu dochodów z podatku PIT. Wartość tej dynamiki cechuje się jednak dużą różnorodnością, niezależną od wielkości ośrodka miejskiego. Wysoka zmienność dynamiki odnosi się także do wpływów z tytułu podatku CIT. W tym przypadku część z miast w okresie 2009-2014 notowała ujemną wartość dynamiki, aczkolwiek nie było to również związane z ich wielkością. Przykładowo ujemna wartość dynamiki dochodów z tytułu podatku CIT dotyczyła m.in. największego z badanych miast, tj. Warszawy - por. rys. 2.

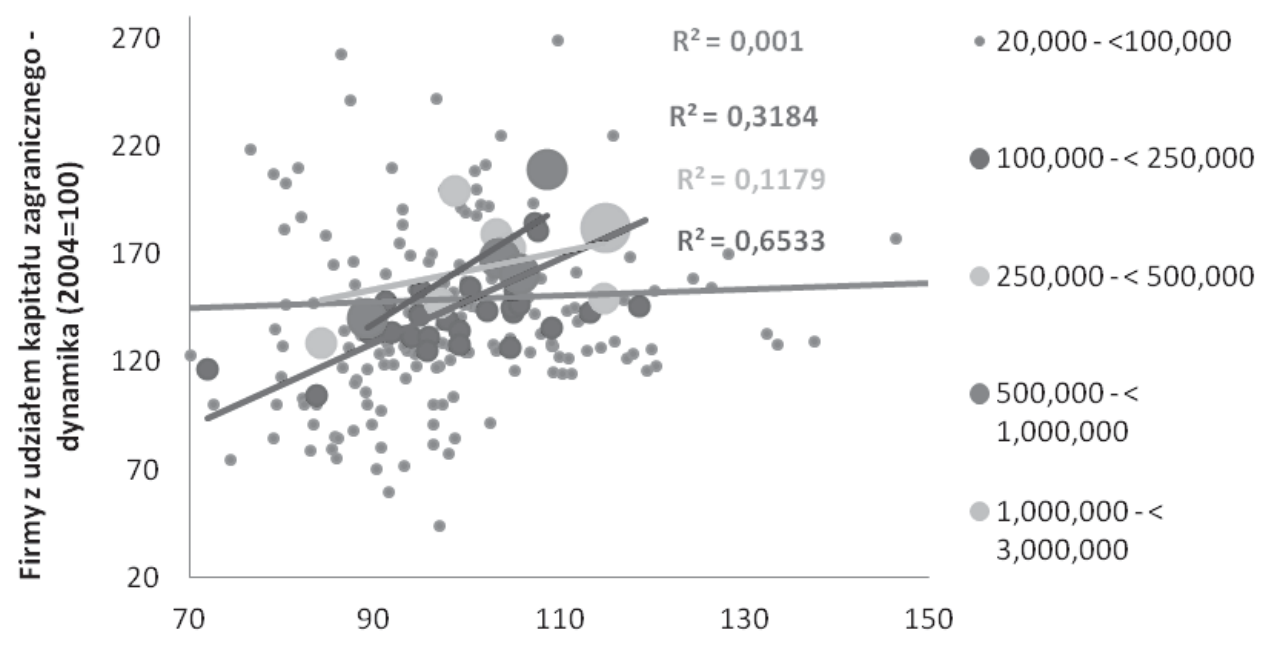

Firmy prowadzone przez osoby fizyczne - dynamika (2004=100)

Rys. 1. Dynamika zmian w wymiarze gospodarczym rozwoju miast w latach 2004-2014 Źródło: opracowanie własne na podstawie danych GUS-u.

Analiza dynamiki sytuacji społecznej badanych miast, szczególnie w wymiarze odnoszącym się do bezrobocia, wykazuje pogorszenie sytuacji głównie w dużych miastach w latach 2009-2014 - por. rys. 3. Dynamika wzrostu liczby bezrobotnych, ujęta jako procent liczby ludności w wieku produkcyjnym, w dużych miastach jest zdecydowanie wyższa od tego rodzaju dynamiki dla miast mniejszych, tj. od 20 tys. do 100 tys. mieszkańców. Podobna jest natomiast - zarówno w miastach większych, jak i mniejszych, dynamika liczby gospodarstw domowych korzystających z pomocy społecznej. 


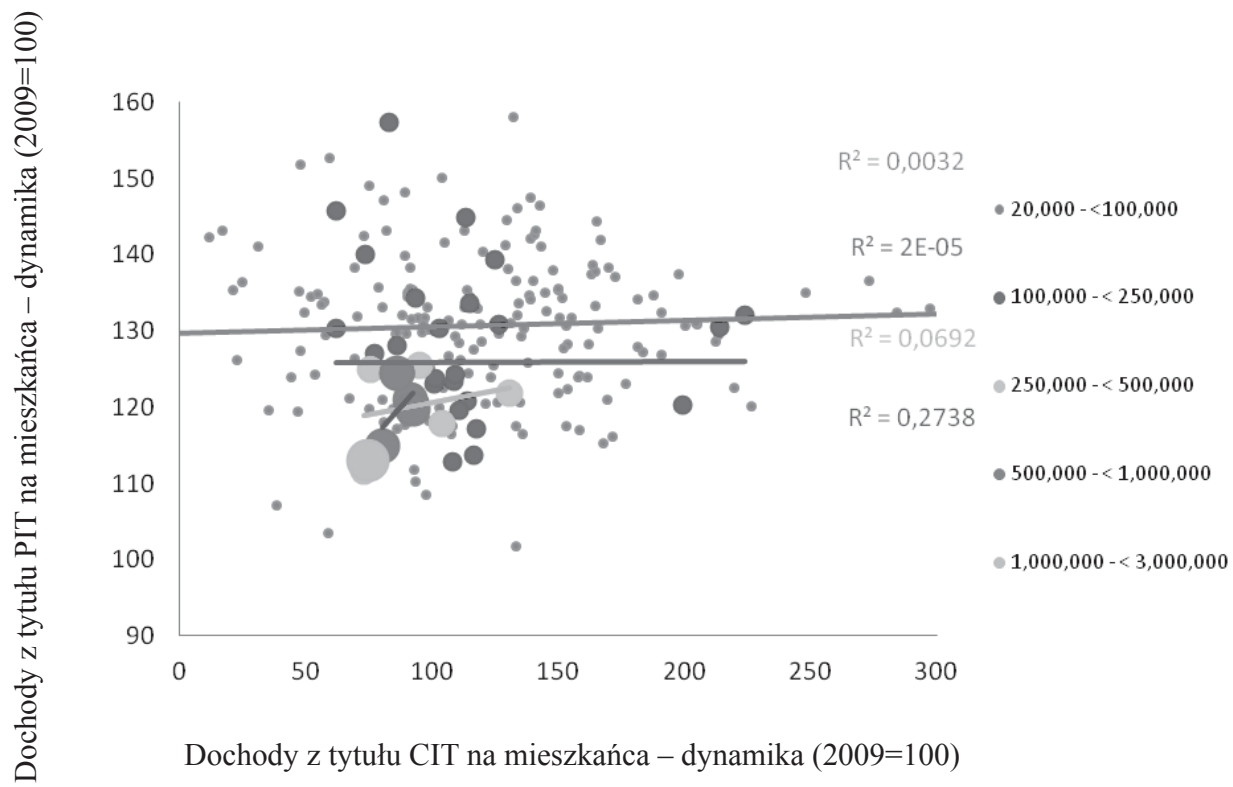

Rys. 2. Dynamika zmian w wymiarze sytuacji finansowej miast w latach 2009-2014 Źródło: opracowanie własne na podstawie danych GUS-u.

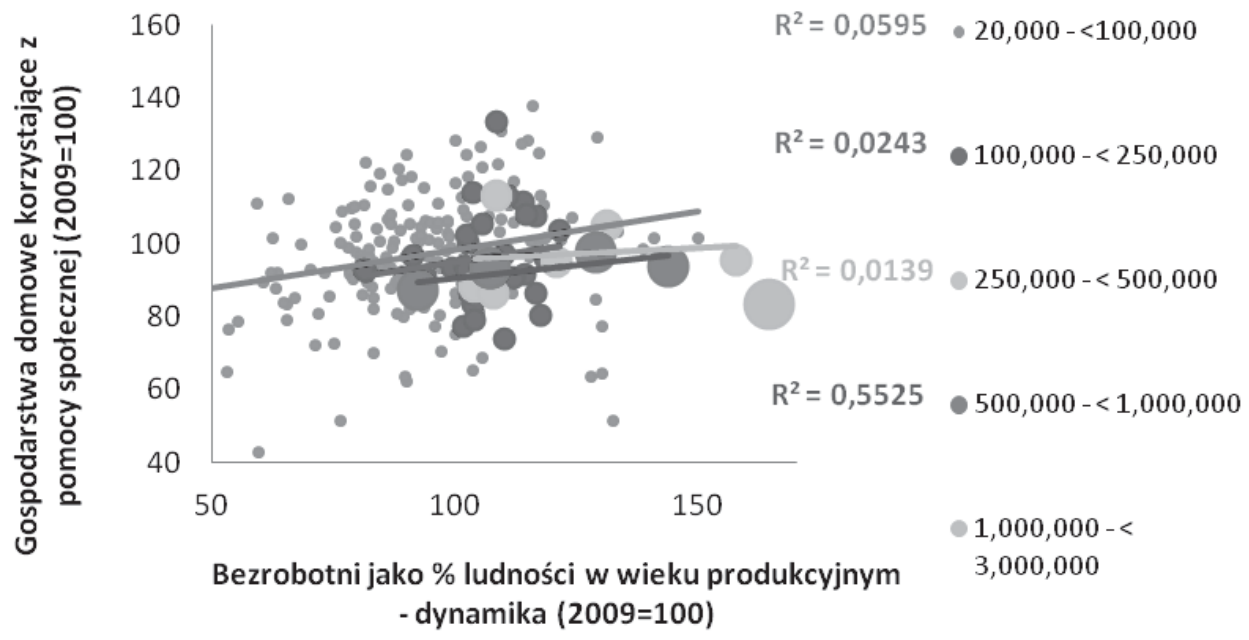

Rys. 3. Dynamika zmian w wymiarze sytuacji społecznej miast w latach 2009-2014 Źródło: opracowanie własne na podstawie danych GUS-u. 
Dynamika zmian sytuacji demograficznej analizowanych ośrodków miejskich - por. rys. 4 -wykazuje znaczne zróżnicowanie sytuacji ludnościowej zarówno miast mniejszych, jak i większych. Większe ośrodki miejskie cechują się przede wszystkim spadkiem liczby ludności (wskaźnik dynamiki poniżej 100), choć w tej grupie m.in. Warszawa stanowi wyjątek, cechując się dodatnim przyrostem liczby mieszkańców. Natomiast ośrodki mniejsze (od 20 tys. do 100 tys. mieszkańców) wyróżniają się nasileniem procesów starzenia się (wskaźniki dynamiki powyżej 140). Procesy starzenia się społeczności zachodzą także w miastach większych (tj. od 100 tys. do 250 tys. mieszkańców, od 250 tys. do 500 tys. mieszkańców, od 500 tys. do $1 \mathrm{mln}$ mieszkańców), aczkolwiek ich dynamika zamyka się w przedziale od 100 do 140 w latach 2004-2014.

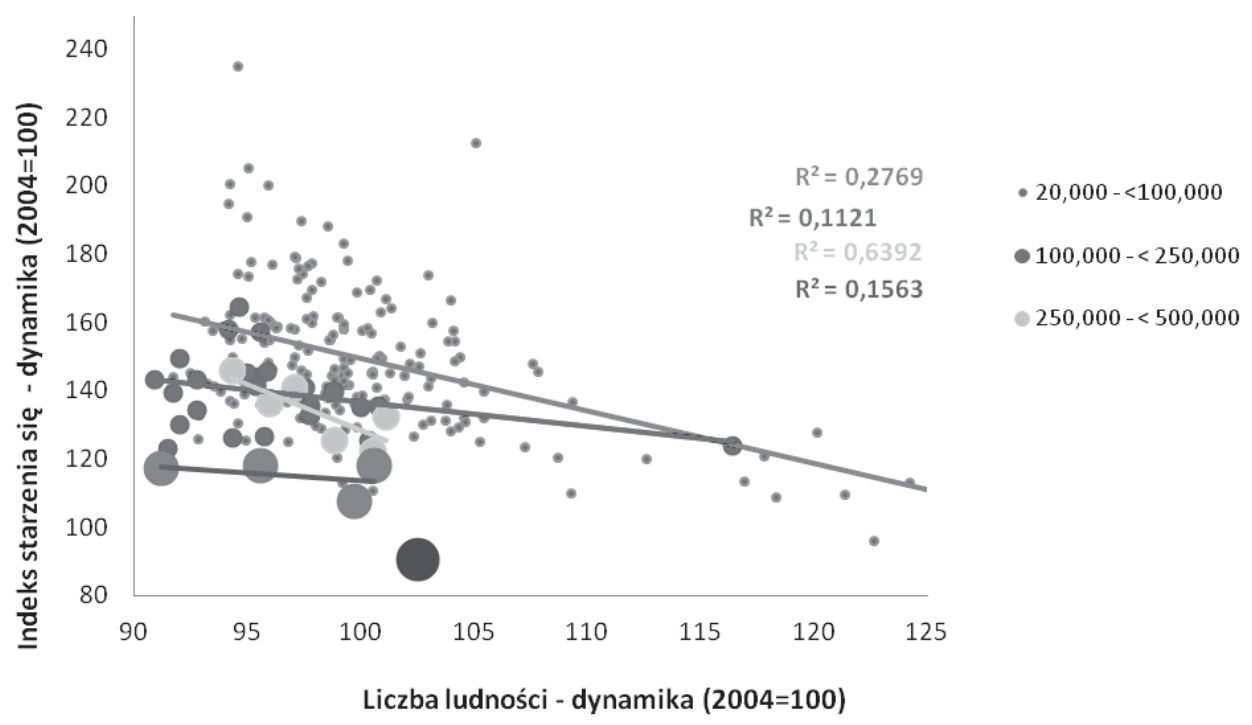

Rys. 4. Dynamika zmian w wymiarze demograficznym rozwoju miast w latach 2004-2014 Źródło: opracowanie własne na podstawie danych GUS-u.

\section{Podsumowanie}

Sytuacja gospodarcza badanych miast wskazuje, iż poziom zróżnicowania dynamik przedsiębiorczości i umiędzynarodowienia jest zróżnicowany w analizowanych grupach ośrodków miejskich, co sugeruje, że nie w każdym przypadku duża wielkość miasta przesądza o wyższej dynamice rozwoju.

Dynamika dochodów podatkowych miast z tytułu podatku CIT i PIT stanowi pewne przybliżenie sytuacji gospodarczej przedsiębiorstw działających w ośrodkach miejskich (zyskowność działalności oraz poziom płac). Spadek dochodów bud- 
żetowych z tytułu podatku CIT w latach 2009-2014 głównie w większych miastach świadczy o pogorszeniu sytuacji gospodarczej firm. Równocześnie w latach 2009-2014 zarówno w miastach mniejszych, jak większych wzrastają dochody budżetów z tytułu podatku PIT, co wskazuje na wzrost wynagrodzeń, które, jak pokazują badania, nie są stricte powiązane z kondycją finansową przedsiębiorstw (szczególnie w dużych miastach).

Brak bezpośredniej relacji między wielkością dynamik wzrostu a wielkością ośrodka miejskiego widoczny jest w przypadku badanych miast szczególnie w wymiarze społecznym związanym ze zwiększeniem bezrobocia. Pogorszenie sytuacji gospodarczej przedsiębiorstw działających w większych miastach w latach 2009-2014 (międzynarodowy kryzys finansowy i spowolnienie gospodarcze) skutkuje znacznymi wzrostami liczby bezrobotnych.

W wymiarze demograficznym większe miasta cechują szybsze tendencje depopulacyjne, przy równocześnie zachodzących procesach starzenia się mieszkańców. Niemniej, to w przypadku mniejszych miast procesy starzenia się występują z większą intensywnością, przy niemal zachowanym potencjale liczby mieszkańców z 2004 roku.

Zaprezentowane wyniki badań potwierdzają założenia będące efektem koncepcji hybrydyzacji rozwoju, odnoszące się do: znaczącego zróżnicowania poziomu dynamik, braku jednoznacznych powiązań między dynamiką rozwoju a wielkością ośrodka miejskiego oraz ograniczonymi możliwościami formułowania ogólnych zależności w zakresie dynamiki rozwoju miast.

Wykazane w badaniach znaczące zróżnicowanie sytuacji gospodarczej, finansowej, społecznej i demograficznej wskazuje na potrzebę indywidualnego podejścia do programowania rozwoju miast w zależności od ich wielkości. Zróżnicowanie dynamik dotyczy każdej z wyróżnionych grup z osobna. Wskazuje to na konieczność nowego spojrzenia na dotychczas ugruntowane przekonania zakładające, iż w przypadku większych ośrodków, tj. o większej liczbie mieszkańców i większej gęstości zaludnienia, procesy rozwoju przebiegają w sposób bardziej dynamiczny.

\section{Literatura}

David P.A., 2005, Path dependence in economic process: Implications for policy analysis in dynamical systems contexts, [w:] Dopfer K. (ed.), The Evolutionary Foundations of Economics, Cambridge University Press, Cambridge, s. 151-194.

Drobniak A., 2016a, Dynamika rozwoju miast w kontekście ich wielkości i rangi, Studia Ekonomiczne Regionu Łódzkiego (w druku).

Drobniak A., 2016b, Hybridization of urban development - resilience and development dynamics of cities in Poland, RSA Annual Conference, Graz, Austria, 3rd-6th April 2016.

Drobniak A. (ed.), 2014, Urban resilience concept and post-industrial cities in Europe, University of Economics in Katowice, Helion, Katowice, s. 364. 
Duranton G., 2007, Urban evolutions: The fast, the slow, and the still, American Economic Review, 97(1), s. 197-221.

Golubchikov O., Badyina A., Makhrova A., 2014, The hybrid spatialities of transition: Capitalism, legacy and uneven urban economic restructuring, Urban Studies, 51(4), March, s. 617-633.

Harvey D., (2005), A Brief History of Neoliberalism. Oxford University Press, Oxford.

http://developer.telerik.com/featured.

http://www.afdc.energy.gov/vehicles/electric_basics_hev.html.

http://www.chemicool.com/definition/hybridization.html.

http://www.dictionary.com/browse/hybrid.

http://www.iba-hamburg.de.

http://www.opde.net/en/technologies/hybrid-systems.

http://www.rehab.research.va.gov/jour/09/46/3/Kobetic.html.

Leetmaa K., Tammaru T., Anniste K., 2009, From priority-led to market-led suburbanisation in a post-communist metropolis, Tijdschrift voor Economische en Sociale Geografie, vol. 100, no. 4, s. 436-453.

Massey D.B., 1984, Spatial Divisions of Labour: Social Structures and the Geography of Production, Methuen, New York.

McCann Ph., Ortega-Argilés R., 2015, Smart specialization, regional growth and applications to European Union Cohesion Policy, Regional Studies, vol. 49, no. 88, s. 1294.

Pavlínek P., 2003, Alternative theoretical approaches to post-communist transformations in Central and Eastern Europe, Acta Slavica Iaponica, vol. 20, s. 85-108.

Rio Declaration 1992 on Environment and Development, United Nations.

Smith A., Swain A., 1998, Regulating and institutionalizing capitalisms: The micro-foundations of transformation in Eastern and Central Europe, [w:] Pickles J., Smith A. (eds.) Theorising Transition: The Political Economy of Post-communist Transformations, Routledge, London, s. 25-53.

Suchaček J., 2012, On the emergence of resilience and adaptability: An evolutionary perspective, Journal of Economics and Management, vol. 10, s. 22-30.

Suchaček J., Krpcová M., Stachonová M., 2012, Transition and resilience in Czech post-industrial towns: The case of Ostrava and Karviná. Regions Magazine, vol. 286, iss. 1, s. 17-20.

Sýkora L., 2009, Post-socialist cities, [in:] Kitchin R., Thrift N. (eds.) International Encyclopedia of Human Geography, vol. 8, Elsevier, Oxford, s. 387-395.

Sýkora L., Bouzarovsky S., 2012, Multiple transformations: Conteptualising the post-communist urban transition, Urban Studies, vol. 49, iss. 1, s. 43-60.

Wink R., 2012, Economic resilience as the evolutionary concept for the post-industrial regions: The case of Leipzig and Halle, Journal of Economics and Management, vol. 10, s. 60-72.

Wink R., 2014, Regional economic resilience: European experiences and policy issues, Raumforschung und Raumordung, vol. 72, iss. 2, April, s. 85-91.

Żółkowska E.J., 2016, Metodyka geografii osadnictwa, Oficyna Wydawnicza Politechniki Warszawskiej, Warszawa, s. 127-128. 